\title{
LUMBAR EPIDURAL ANAESTHESIA AND SENSORY PROFILES IN TERM PREGNANT PATIENTS
}

\author{
Teruel de Campo, Maximo Macias-Loza, Harry Cohen and Anibal Galindo
}

Abstract

\begin{abstract}
Sensory profiles of lumbar epidural anaesthesia were studied in 57 patients during active labour. The local anaesthetics used were chloroprocaine three per cent with and without epinephrine, chloroprocaine two per cent, bupivacaine 0.25 per cent and a mixture of chloroprocaine three per cent and bupivacaine 0.5 per cent.

A common pattern of spread was found for all local anaesthetic solutions with the onset of the block affecting the dermatomes innervated by the thinnest nerve roots $\left(T_{12} L_{1}\right)$. There was a percentage of failure to block the thickest nerve root $\left(\mathrm{S}_{1}\right)$. Inguinal and suprapubic discomfort ("missing segment") occurred when $S_{1}$ was not blacked.

Under the conditions of this experiment, the addition of bupivacaine to chloroprocaine did not increase the duration of the blockade significantly.
\end{abstract}

LUMBar ePIDURAL ANaEsTHesia is one of the most important therapeutic interventions for the relief of pain in pregnant patients at term. However, this relief may be incomplete, in the form of a "missing segment." responsible for inguinal and/or suprapubic discomfort after successful and "complete" block (to pinprick) of the lumbar and sacral dermatomes. Ducrow' has found a 6.7 per cent incidence of unblocked segments in a series of 920 epidural anaesthetics for labour. It was postulated that a failure of spread of the local anaesthetic solutions within the epidural space would explain the "missing segment."

Galindo, et al..$^{2}$ studied patients undergoing general surgical procedures under lumbar epidural anaesthesia. They established a correlation between the diameler of the nerve roots and the penetration of the anaesthetic solution by studying the spread of analgesia as function of time ("sensory profile"). Onset of block of larger nerve roots was slower and they required higher concentrations of anaesthetics.

Taking these previous observations into consideration, we conducted studies to establish if sensory profiles of pregnant patients at term were similarly related to nerve root diameter, as had been proven for the general surgical population; to determine any possible correlation between failure to block the largest spinal nerve roots and

Teruel de Campo, M.D., Assistant Professor, Maximo Macias-Loza, M.D., Instructor, Harry Cohen, M.D. Professor, Anibal Galindo, M.D., Professor, Department of Anesthesiology, University of Colorado Health Sciences Center, Denver, Colorado 80262 and Department of Anesthesiology, University of Miami, Miami, Florida.

Canad. Anaesth. Soc. J., vol. 27, no. 3, May 1980 the persistence of inguinal and suprapubic pain during labour; and to demonstrate to what extent the widely accepted local anaesthetic solutions used in obstetrics could modify the sensory profiles of lumbar epidural block and to determine their effectiveness in abolishing inguinal and suprapubic pain.

\section{METHODS}

Observations were made in 57 pregnant patients in active labour in whom lumbar epidural anaesthesia was administered for vaginal delivery or Caesarean section. A plastic catheter was advanced not more than $3 \mathrm{~cm}$ into the lumbar epidural space through a 17-gauge directional needle inserted at the level $\mathrm{L}_{3-4}$.

Patients were placed in the supine position with left uterine displacement. A test dose of $2 \mathrm{ml}$ of local anaesthetic solution was administered, followed three minutes later by a $10 \mathrm{ml}$ "loading dose." Onset of anaesthesia was defined as the beginning of hypalgesia to pinprick. Measurements were made every minute in all dermatomes from $T_{4}$ to $S_{5}$. Graphs were constructed for each patient relating dermatomes anaesthetized to time (sensory profile). Inguinal and suprapubic discomfort were graded from $1+$ to $4+$. The minimal discomfort was usually manifested not by pain, but by awareness of uterine contraction. When the patient was not aware of the contraction at the time when the amniotic fluid pressure recording showed the peak of the contraction, it was considered that discomfort was completely abolished. With this method we were able to compare the profiles of the local anaesthetic sol- 
utions with the changes observed during the acute period of labour. The profiles were analyzed as follows: time of onset of hypalgesia; time required to block $T_{10}, S_{1}$ and $S_{3}$ to $S_{5}$; and the duration of anaesthesia expressed as the interval between onset and two-dermatome regression. Time to onset of anaesthesia was defined as the time when hypalgesia to pinprick was first detected. Because of the difficulty of discriminating among $S_{3}, S_{4}$, and $S_{5}$ dermatomes, they were considered as one unit $\left(S_{3}-S_{5}\right)$.

The lumbar epidural anaesthetics were administered by three of the authors while the sensory profiles were evaluated by two of them. No discussion of the findings took place until after the study had been completed.

The local anaesthetic solutions selected for the study were: chloroprocaine two per cent and three per cent without epinephrine, chloroprocaine three per cent with epinephrine $1: 300,000$, bupivacaine 0.25 per cent and a mixture of chloroprocaine three per cent and bupivacaine 0.5 per cent in equal volumes.

Values of mean and standard deviation were established for all time intervals necessary to obtain sensory block. The different anaesthetic solutions were compared by means of the " $t$ " test for unpaired data. Criteria of significance were established at a value of less than 0.05 .

\section{RESULTS}

A common pattern of spread was noted for all anesthetic solutions. Hypalgesia occurred first at the level of $T_{12}-L_{1}$; it advanced in an orderly sequence through the lumbar and thoracic segments. However, the downward spread to the sacral segments was not uniform; it occurred first in the lower segments $\left(S_{3}-S_{5}\right)$ and only after some delay did the second and, finally, the first, sacral segments become blocked.

Failure to block the largest spinal nerve root $\left(S_{1}\right)$ was related to the concentration of the anaesthetic solution (Table I). The patient in whom $S_{1}$ did not become completely blocked complained of inguinal and suprapubic discomfort in the form of pressure and awareness during uterine contraction. This discomfort was present despite complete block of dermatomes $T_{10}$ to $L_{5}$ and $S_{2}$ and $S_{s}$ as determined by pinprick; its disappearance coincided with the blockade of $S_{1}$ and reoccurred during uterine contractions when the first sacral nerve root recovered.

Time of onset of anaesthesia was similar for all anaesthetic solutions. The addition of a very low
TABLE I

\begin{tabular}{|c|c|c|c|}
\hline & \multicolumn{2}{|c|}{ Chloroprocaine } & \multirow[b]{2}{*}{$p$} \\
\hline & $\begin{array}{c}3.0 \text { per cent } \\
12 \mathrm{ml} \\
\mathrm{N}=10\end{array}$ & $\begin{array}{c}2.0 \text { per cent } \\
12 \mathrm{ml} \\
\mathrm{N}=16\end{array}$ & \\
\hline Onset $\left(T_{12}\right)$ & $\begin{array}{l}3.15 \\
(0.75)\end{array}$ & $\begin{array}{c}2.99 \\
(0.76)\end{array}$ & NS \\
\hline Time to block $T_{10}$ & $\begin{array}{l}5.18 \\
(1.06)\end{array}$ & $\begin{array}{c}5.70 \\
(2.06)\end{array}$ & NS \\
\hline Time to block $S_{1}$ & $\begin{array}{l}16.88 \\
(5.32)\end{array}$ & $\begin{array}{l}15.65 \\
(4.22)\end{array}$ & NS \\
\hline $\begin{array}{l}\text { Percent failure to } \\
\text { block } S_{1}\end{array}$ & 10 & 43.75 & \\
\hline Time to block $S_{3}-S_{S}$ & $\begin{array}{c}6.79 \\
(1.28)\end{array}$ & $\begin{array}{c}7.42 \\
(2.64)\end{array}$ & NS \\
\hline $\begin{array}{l}\text { Regression of two } \\
\text { segments }\end{array}$ & $\begin{array}{c}36.66 \\
(10.32)\end{array}$ & $\begin{array}{l}33.85 \\
(8.20)\end{array}$ & NS \\
\hline $\mathrm{ml} /$ Segment & $\begin{array}{c}0.69 \\
(0.052)\end{array}$ & $\begin{array}{c}0.89 \\
(0.041)\end{array}$ & 0.001 \\
\hline
\end{tabular}

Values expressed as mean ( \pm standard deviation).

TABLE II

\begin{tabular}{|c|c|c|c|}
\hline & \multicolumn{2}{|c|}{ Chloroprocaine } & \multirow[b]{2}{*}{ p } \\
\hline & $\begin{array}{c}3.0 \text { per cen } \\
12 \mathrm{ml} \\
\mathrm{N}=10\end{array}$ & $\begin{array}{c}3.0 \text { per cent } \\
\text { with } \\
\text { epinephrine } \\
1: 300,000 \\
12 \mathrm{ml} \\
\mathrm{N}=10\end{array}$ & \\
\hline Onset $\left(T_{12}\right)$ & $\begin{array}{c}3.15 \\
(0.75)\end{array}$ & $\begin{array}{c}4.75 \\
(1.39)\end{array}$ & 0.01 \\
\hline Time to block $T_{10}$ & $\begin{array}{c}5.18 \\
(1.06)\end{array}$ & $\begin{array}{c}7.35 \\
(1.15)\end{array}$ & 0.001 \\
\hline Time to block $S_{1}$ & $\begin{array}{l}16.88 \\
(5.32)\end{array}$ & $\begin{array}{l}17.8 \\
(3.35)\end{array}$ & NS \\
\hline $\begin{array}{l}\text { Per cent failure to } \\
\text { block } S_{1}\end{array}$ & 10 & 0 & \\
\hline Time to block $S_{3}-S_{5}$ & $\begin{array}{c}6.79 \\
(1.28)\end{array}$ & $\begin{array}{l}8.82 \\
(3.29)\end{array}$ & NS \\
\hline $\begin{array}{l}\text { Regression of two } \\
\text { segments }\end{array}$ & $\begin{array}{l}36.66 \\
(10.32)\end{array}$ & $\begin{array}{l}47.50 \\
(8.86)\end{array}$ & NS \\
\hline $\mathrm{ml} /$ Segment & $\begin{array}{c}0.69 \\
(0.052)\end{array}$ & $\begin{array}{c}0.73 \\
(0.079)\end{array}$ & NS \\
\hline
\end{tabular}

Values expressed as mean ( \pm standard deviation).

concentration of epinephrine delayed onset, but had little effect on the spread or duration of chloroprocaine anaesthesia (Table II).

The duration of anesthesia following administration of the mixture of chloroprocaine three per cent and bupivicaine 0.5 per cent was approximately equal to that observed with chloroprocaine alone (Table III) and, therefore, much shorter than the duration of anaesthesia obtained with bupivacaine alone (Table IV). 
TABLE III

\begin{tabular}{lccc}
\hline \hline & \multicolumn{3}{c}{$\begin{array}{c}\text { Bupivacaine } \\
0.5 \text { per cent and }\end{array}$} \\
& $\begin{array}{c}\text { Chloroprocaine } \\
\text { 2 per cent } \\
12 \mathrm{ml}\end{array}$ & $\begin{array}{c}\text { 3 per cent } \\
6 \mathrm{ml} \text { of each }\end{array}$ & \\
& $\mathrm{N}=16$ & $\mathrm{~N}=11$ & $\mathrm{p}$ \\
\hline Onset $\left(\mathrm{T}_{12}\right)$ & 2.99 & 2.64 & $\mathrm{NS}$ \\
& $(0.76)$ & $(0.55)$ & \\
Time to block $\mathrm{T}_{10}$ & 5.70 & 4.31 & 0.05 \\
& $(2.06)$ & $(0.98)$ & $\mathrm{NS}$ \\
Time to block $\mathrm{S}_{1}$ & 15.65 & 15.92 & \\
& $(4.22)$ & $(3.89)$ & \\
Per cent failure to block $\mathrm{S}_{1}$ & 43.75 & 36.36 & $\mathrm{NS}$ \\
Time to block $\mathrm{S}_{3}-\mathrm{S}_{5}$ & 7.42 & 5.90 & \\
& $(2.64)$ & $(1.20)$ & $\mathrm{NS}$ \\
Regression of two segments & 33.85 & 35.01 & \\
& $(8.20)$ & $(10.50)$ & 0.001 \\
ml/Segment & 0.89 & 0.67 & \\
& $(0.041)$ & $(0.035)$ & \\
\hline
\end{tabular}

Values expressed as mean ( \pm standard deviation).

TABLE IV

\begin{tabular}{|c|c|c|c|}
\hline & $\begin{array}{c}\text { Bupivacaine } \\
0.25 \text { per cent } \\
12 \mathrm{ml} \\
N=10\end{array}$ & $\begin{array}{c}\text { Bupivacaine } \\
0.5 \text { per cent } \\
\text { chloroprocaine } \\
3 \text { per cent } \\
6 \mathrm{ml} \text { of each } \\
\mathrm{N}=11\end{array}$ & $\mathbf{p}$ \\
\hline Onset & $\begin{array}{c}2.90 \\
(1.58)\end{array}$ & $\begin{array}{c}2.64 \\
(0.55)\end{array}$ & NS \\
\hline Time to block $\mathbf{T}_{10}$ & $\begin{array}{c}6.35 \\
(2.62)\end{array}$ & $\begin{array}{c}4.31 \\
(0.98)\end{array}$ & 0.05 \\
\hline Time to block $S_{1}$ & $\begin{array}{l}20.25 \\
(8.53)\end{array}$ & $\begin{array}{l}15.92 \\
(3.89)\end{array}$ & NS \\
\hline Per cent failure to block $S_{1}$ & 40 & 36.36 & \\
\hline Time to block $S_{3}-S_{5}$ & $\begin{array}{c}9.06 \\
(0.03)\end{array}$ & $\begin{array}{c}5.90 \\
(1.20)\end{array}$ & NS \\
\hline Regression of two segments & $\begin{array}{l}123.33 \\
(5.77)\end{array}$ & $\begin{array}{c}35.01 \\
(10.50)\end{array}$ & 0.001 \\
\hline $\mathrm{ml} /$ Segment & $\begin{array}{l}0.88 \\
(0.085)\end{array}$ & $\begin{array}{c}0.67 \\
(0.035)\end{array}$ & 0.001 \\
\hline
\end{tabular}

Values expressed as mean ( \pm standard deviation).

\section{Discussion}

These observations demonstrated the correlation between delay in blocking a given dermatome and the size of its corresponding nerve root. This applies to pregnant patients in the same way as to the non-pregnant population.

The onset of anaesthesia was consistently observed first at $T_{12}$ and immediately thereafter in $\mathrm{S}_{3}-\mathrm{S}_{5}$. This may be explained by the smaller cross-sectional area of these sacral nerve roots.
In Figure 1, the nerve root size as measured by Kolliker (quoted by Ingbert ${ }^{3}$ ) has been plotted according to their dermatome distribution. The graphs obtained in this manner coincide with the sensory profile where time as latency to block of each dermatome replaces cross-sectional area. The dependence of the sensory profiles on nerve root size occurred for all the anaesthetic solutions used in this study (Figure 2).

Although several studies of nerve root size were available, Kolliker's were selected because 


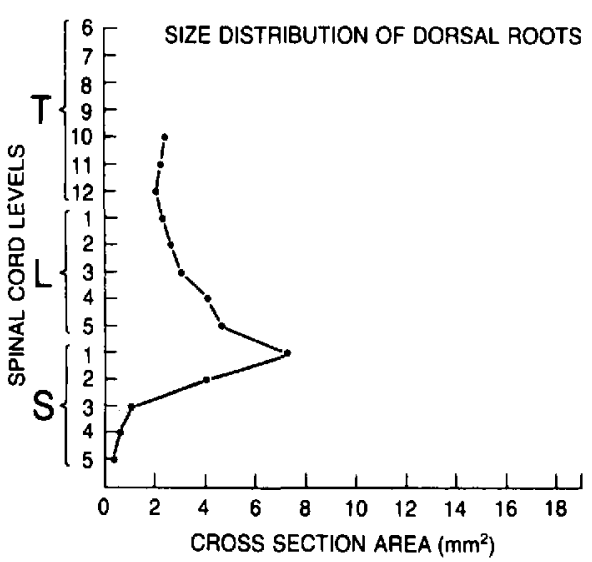

Figure 1 This diagram shows the correlation between each spinal nerve root and its cross-sectional area, as measured by Kolliker (quoted by Ingbert $^{3}$ ).

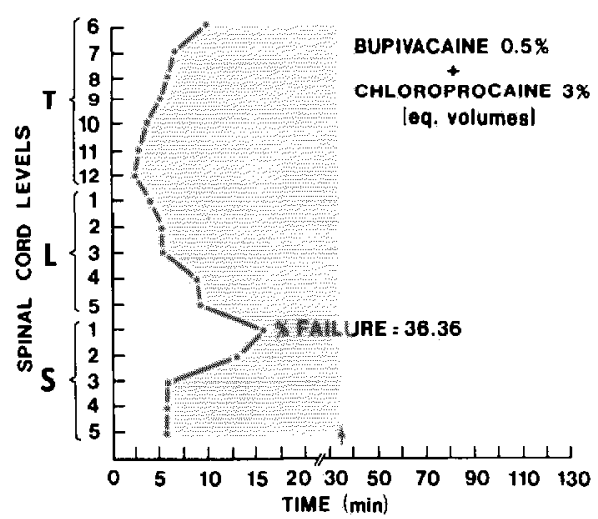

Figure 2 Sensory profile constructed using the mean "time to block" for each nerve root which resulted when the mixture of $6 \mathrm{ml}$ of bupivacaine $0.5 \mathrm{per}$ cent and $6 \mathrm{ml}$ of chloroprocaine 3 per cent was injected into the lumbar epidural space. The arrow indicates the time of regression of the upper (wo dermatomes.

The sensory profiles for the other anesthetic solutions were similar.

they were done in nerve roots with the connective tissue intact, which may represent a barrier for local anaesthetic penetration.

The presence of inguinal or suprapubic pain has been related to the lack of spread of anaesthetic solutions within the epidural space. $L_{1}$ has been incriminated as the segment most frequently involved; however, sensory profiles have not been published showing whether the small area belonging to $S_{1}$ (lateral aspect of the foot) had been tested. Because we found inguinal discomfort in cases where $\mathrm{L}_{1}$ was blocked, as evaluated by pinprick, we believed that it represented a referred pain directly related to the lack of penetration of anaesthetic solutions into the first sacral segment. None of the patients in whom $S_{1}$ was unblocked had complete relief of pain. Only when $S_{1}$ was anaesthetized were the patients free of discomfort and unaware of the uterine contractions at their peak, as measured by monitoring of amniotic fluid pressure.

The inguinal discomfort or pain can be abolished with more concentrated solutions. Chloroprocaine three per cent, with or without epinephrine, produced block of $S_{1}$ and complete relief of suprapubic pain in about 90 per cent of the patients. The other local anaesthetic solutions studied had a failure rate as high as $\mathbf{4 3 . 7 5}$ per cent (chloroprocaine two per cent). However, complete relief of the suprapubic discomfort may not be desirable, since the patient could simultaneously lose awareness of uterine contractions and maintenance of the muscle tone of the pelvic floor which is necessary during the second stage of labour. It should be noted that, with lower concentrations, $\mathrm{T}_{10^{-}}-\mathrm{T}_{12}$ are consistently blocked, abolishing a very important component of the labour pain.

Under the conditions of these observations, the combination of chloroprocaine with bupivacaine did not lengthen the duration of the block, as was expected. ${ }^{4}$ This finding was later confirmed by Cohen, et $a l^{5}$ in a randomized study using higher concentrations of local anaesthetic solution (chloroprocaine 3.0 per cent; bupivacaine 0.375 per cent and chloroprocaine 1.5 per cent; bupivacaine 0.5 per cent). An in vitro study by one of the authors (A.G.), ${ }^{6}$ already completed, supports the finding that the mixture of commercially available solutions may not be desirable. The $\mathrm{pH}$ of chloroprocaine one per cent is 3.56 , the $\mathrm{pH}$ of bupivacaine 0.25 per cent is 5.80 , while the $\mathrm{pH}$ of the mixture of chloroprocaine two per cent and bupivacaine 0.5 per cent is 3.60 . When the solutions were applied to the rat sciatic nerve preparation and the change in the amplitude of the nerve action potential were determined after suprathreshold electrical stimulation, it was found that chloroprocaine, alone and in a mixture, had a rapid onset and short duration of action; bupivacaine had a long duration of action; when the $\mathrm{pH}$ of the mixture was adjusted with bicarbonate to 5.56 the solution presented a slower recovery characteristic of bupivacaine. This would explain why the mixture had the 
duration of chloroprocaine and not that of bupivacaine. Therefore the combination of commercially available local anaesthetic solutions does not offer additional advantages and, without modification (e.g., pH adjustment), it is not recommended for the relief of labour pain.

\section{REFERENCES}

1. Ducrow, M. The occurrence of unblocked segments during continuous lumbar epidural analgesia for pain relief in labor. Brit. J. Anaesth. 43: 1172 (1971).

2. Galindo, A., Hernandez, J., Benavidez, O., Ortega de Munoz, S. \& Bonica, J.J. The influence of spinal nerve root diameter. Brit. J. Anaesth. 47: 4 (1975).

3. INGBERT, C.H. An enumeration of the medullated nerve fibers in the dorsal roots of the spinal nerve of man. J. Comp. Neur. 13: 53 (1903).

4. Villia. E.A. \& MarX, G.F. Chloroprocainebupivacaine sequence for obstetric extradual analgesia. Canad. Anaesth. Soc. J. 22: 26 (1975)

5. Cohen, S. \& Thurlow, A. Comparison of a chloroprocaine-bupivacaine mixture with chloroprocaine and bupivacaine used individually for obstetric epidural anesthesia. Anesthesiology $\mathrm{Sl}$ : 288-292 (1979)

6. Galindo, A. \& Whitcher, T. Mixture of local anesthetics: bupivacaine-chloroprocaine. Anesthesiology 51: S-213 (1979).

\section{RÉSUMÉ}

Le profil sensoriel de l'anesthésie épidurale lombaire a été étudié chez 57 parturientes en travail. Les anesthésiques locaux utilisés ont été le chloroprocaine 3 pour cent avec et sans épinéphrine, la chloroprocaïne 2 pour cent, la bupivacaïne 0.25 pour cent et un mélange de chloroprocaïne 3 pour cent et de bupivacaïne 0.5 pour cent.

On a démontré pour toutes les solutions d'anesthésiques locaux un schéma commun de propagation du bloquage avec une installation aux dermatomes innervés par les racines les plus fines $\left(T_{12}, L_{1}\right)$. On a rencontré une proportion d'échecs pour la racine la plus épaisse $\left(S_{1}\right)$ Une insuffisance de blocage de $S_{1}$ a été ressentie sous forme de malaisc aux régions inguinales et sus-pubiennes.

Lors de cette étude, l'addition de bupivacaïne à la chloroprocaïne n'a augmenté la durée du blocage de façon significative. 